\title{
Etika sebagai Landasan Moral Pembangunan Ekonomi di Indonesia
}

\section{Suroso Imam Zadjuli}

The development of economy constitutes the efforts of economists in every field of trading activities. The goal of those activities is to increase the values of life in keeping the existences and the life needs. To develop economy of nation not only to enlarge the real added values but also to build the character building of society toward more better. In developing economy needs business ethics as moral-base that implies to brotherhood and not free fight competition. In this sense, the religious ethics can be consider to become ethics and moral-base of economy activities.

Kata-kata kunci: sistem ekonomi, etika Islam, masyarakat madani

O embangunan ekonomi adalah merupakan usaha para pelaku ekonomi baik masyarakat/keluarga, Pemerintah, Swasta, maupun para eksportir serta importir yang melakukan perdagangan antar negara untuk meningkatkan nilai kehidupan lebih baik guna menjaga eksistensi dan kebutuhan hidupnya. Dalam pembangunan perekonomian suatu bangsa selain bertujuan untuk meningkatkan nilai tambah secara riil/nyata juga diusahakan untuk meningkatkan tata nilai kehidupan masyarakat ke arah yang lebih baik.

Dalam usaha di bidang ekonomi diperlukan etika bisnis yang bermoral sehingga akan menimbulkan kegiatan ekonomi kemitraan (brother hood) dan jauh dari kegiatan ekonomi yang berlandaskan per saingan bebas yang saling mematikan (free fight competion).

Dalam religious ethics (etika yang agamis) dapat dievaluasi secara historical analysis dimana pada saat zaman jahiliyah berkembang dengan pesatnya, dan saat umat manusia kehilangan pegangan hidupnya pada tanggal 12 Rabi'ul Awwal, hari Isnain (Senin) atau pada tanggal $20 \mathrm{April} 571$ Masehi lahirlah seorang Bayi yatim dari keluarga Abdulah yang sangat sederhana di kota Makkah. Abdullah sang ayah dari Bayi tersebut meninggal sekitar 3 bulan sebelum si Bayi dilahirkan. Ibunda Nabi bernama Aminah binti Wahab dari suku Quraisy yang sangat disegani waktu itu. Kelahiran Bayi tersebut disambut dengan suka cita oleh neneknyaAbdul Mutholib yang kemudian dengan kasih sayang bayi tersebut dibawanya ke kaki Ka'bah dan diberi nama Muhammad.

Tempat kelahiran Nabi Muhammad tersebut tepatnya sekitar 300 meter di sebelah Timur Laut Ka'bah. Rumah yang berkaveling sekitar 200 meter persegi tersebut memang sangat sederhana dan masih ada hingga sekarang. Perlu diketahui rumah kelahiran Rosulullah tersebut sekarang dijadikan perpustakaan dua lantai, 
namun tetap dengan kesederhanaannya. Bagi siapa saja umat Muhammad yang berkesempatan melihat sendiri rumah tersebut pasti menangis, sebab betapa sederhananya rumah itu, bila dibandingkan dengan keagungan asmanya. Rumah tersebut pernah diperbaiki dua kali namun tetap dipertahankan kesederhanaannya. Nilai bangunan tersebut bila dipindahkan ke Surabaya di Jawa Timur, harganya masih berada jauh di bawah/lebih murah bila dibandingkan dengan harga rumah tipe Perumnas BTN yang berada di Indonesia.

Allah berfirman, "Dan tiadalah Kami mengutus engkau hai Muhammad, melainkan untuk menjadi rahmat bagi semesta alam." (Q.S. Anbiyaa' 107)

Sesungguhnya telah ada pada diri Rosulullah itu contoh teladan yang baik bagimu; ialah bagi orang yang mengharapkan rahmatAllah dan kedatangan hari kiamat dan ia banyak ingat menyebut akan Allah. (Q.S. Al-Ahzaab' 21)

Jadi jelas bahwa Muhammad diutus Allah SWT. bukan hanya untuk kebaikan orang Islam saja, tetapi lebih luas dari itu, yaitu untuk memberikan rahmat baik bagi manusia, makhluk lain serta bagi alam semesta secara keseluruhan baik sewaktu masih hidup di Dunia maupun pada hari Akhir nanti.

Dalam rangka mensuri-tauladan perilaku dan kehidupan Nabi Allah telah memberikan sanjungan dengan:

"Sesungguhnya kamu (Muhammad) memiliki akhlaq yang mulia"

Sewaktu Sayyidatina ra, Aisyah ditanya oleh seorang sahabat tentang perilaku Rosulullah, beliau menjawab:

"Budi pekerti Rosulullah ialah AlQuran"

Dengan uraian tersebut, maka untuk memperoleh tonggak ataupun pegangan dalam pengembangan inspirasi dan cita-cita kaum Muslim maupun yang sekarang masih berstatus Mualaf (baru masuk ataupun baru mempelajari Islam) bahkan kaum NonMuslimpun dapat menggunakan Al-Qur'an dan Al-Hadist sekalipun sebagai kompas untuk mengarungi kehidupan di dunia dan di akhirat nanti.

Pendidikan adalah merupakan kunci utama kebangkitan/keberhasilan dari suatu bangsa. Pendidikan yang sebagian besar dimanifestasikan dalam bentuk baca tulis telah merubah peta keberhasilan bangsabangsa di dunia. Seperti yang tercantum dalam SuratAl'Alaq, ayat 1 sampai dengan 5 yang bermakna sebagai berikut:

- Bacalah dengan nama Tuhanmu yang menciptakan. (1)

- Dia telah menciptakan manusia dari segumpal darah (2)

- Bacalah, dan Tuhanmu itu amat mulia.

(3)

- Yang mengajar (manusia) dengan kalam. (4)

- Dia mengajarkan kepada manusia apa yang tidak diketahuinya. (5)

Dengan awal kelima ayat tersebut Islam, telah merubah peta pendidikan dari bangsa yang tidak berakhlak menjadi bangsa yang berbudi luhur.

Dari beberapa ayat tersebut juga nampak bahwa peranan akal manusia yang memungkinkan berkembangnya ilmu dan teknologi sebagai kelengkapan bekal hidup manusia di dunia maupun di akhirat nanti. Untuk membentuk manusia yang berkualitas/berilmu, jelas memerlukan sistem . pendidikan baik lewat jalur formal maupun non-formal. Dengan pendidikan baik dengan materi umum maupun ilmu agama akan mempertinggi kualitas manusia, yang pada , akhirnya akan dapat pula meningkatkan nilai output bila manusia tersebut berusaha, bekerja dan diiringi doa. 
Islam berasal dari akar kata "Slim" yang berarti damai ataupun selamat. Orang akan memperoleh kedamaian dan keselamatan abadi bila melaksanakan semua ajaran Islam yang bersumberkan dariAl-Qur'an dan Al-Hadist.

Muhammad AliAlkhuli dalam "The Light of islam" mengemukakan:

Islam is a comprehensive religion in the sense it deals with all the major aspects of human life : mind, body, soul, economy, family, politics, ethics, penal laws, worship, inheritance, foods, drinks, marriage, divorce, and all the other major aspect of human life. The reason behind the comprehensiveness of Islam is that since Islam is the last religion it must solve the main problems of man. If man is left without Allah's guidance, the result is chaos: man do nor agree on what is good and what is bad; what is good in a country may be bad in another. How can the world be brought into unity or security if people do not agree ti the right and the wrong? This is Why Islam is made to be comprehensive. The comprehensiveness of Islam aims at helping man solve own problems. It also aims at unifying the ethical values of humans in all place. It also aims at unifying all people and all races through unifying their ethical frame of reference.

However, it is important to add that not all the acts performed by some Muslims are Islamic, because it is a fact Muslims very in the degree of abiding by Islam. In other word, not all that Muslims do can be elated to Islam.

Dengan demikian Islam merupakan suatu Agama yang lengkap/komplit yang berhubungan dan menjelaskan tentang berbagai aspek pokok kehidupan yang meliputi masalah: ekonomi, politik, hukum, keluarga, tubuh, akal/fikiran, kalbu, makanan, minuman, kawin, cerai, filsafat, sejarah contoh-contoh kehidupan masa lalu . dan yang akan datang, yang akan sangat berguna bagi tuntunan umat manusia di bumi ini untuk mencapai kedamaian dan keselamatan yang sejati. Islam merupakan agama penutup yang telah disempurnakan oleh Allah.

Islam dapat memberi petunjuk untuk mencari jalan keluar dari semua permasalahan. Kalau seorang telah meninggalkan petunjukAllah, hasilnya adalah kekacauan. Manusia menjadi tidak dapat membedakan yang buruk dan yang baik, yang salah dan yang benar. Tanpa tuntutan Allah maka sesuatu yang baik dan benar menurut seseorang belum tentu hal tersebut sama persepsinya bagi orang lain. Sesuatu yang baik dan benar untuk suatu negara dinilai jelek dan salah oleh negara lain. Bila hal ini terjadi, maka kekacauan dan peperanganlah yang akan timbul. Dewasa ini telah terjadi peperangan baik di Eropa Timur maupun Timur Tengah karena hal tersebut.

Sebaliknya bila manusia sebagai individu, keluarga, kelompok masyarakat ataupun bangsa, makin dekat dengan ajaran agama (Islam) maka akan makin sedikitlah permasalahan ataupun bencana yang akan dihadapi, sebab bila manusia mendekat sedepa kepada Allah, maka Allah akan mendekat sehasta pada manusia. Jika manusia mendekat sehasta kepada Allah, makaAllah akan mendekat sejengkal pada manusia dan bila manusia mendekat sejengkal pada Allah, maka Allah merapat dan memeluk manusia itu. Bila manusia dapat berhasil merapat dan memeluk Allah ibaratnya, maka Allah akan masuk ke nadi, otak, hati ataupun kalbu manusia itu. Alangkah hebatnya ajaran Islam itu.

Allah berfirman: "Dan carilah pada apa yang telah dianugerahkan Allah kepadamu 
Etika Sebagai Landasan Moral Pembangunan Ekonomi...; Suroso Imam Zadjuli

berupa kebahagiaan negeri akhirat, tetapi janganlah kamu melupakan kebahagiaanmu dari kenikmatan duniawi, dan berbuat baiklah kepada orang lain sebagaimana Allah telah berbuat baik kepadamu, dan janganlah kamu berbuat kerusakan di muka bumi. Sesungguhnya Allah tidak menyukai orang-orang yang berbuat kerusakan.

Dan Rosulullah bersabda:

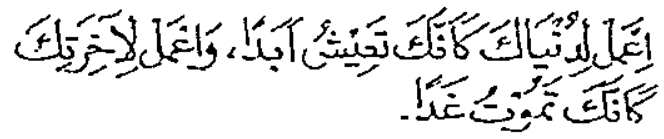

"Berusahalah untuk urusan duniamu seolah-olah kamu akan hidup selamalamanya, dan berusahalah untuk urusan akhiratmu seolah-olah kamu akan mati besok pagi" (Hadits).

Dari firman Allah dan sabda Rosul tersebut di atas maka cita-cita umat manusia, khususnya bagi umat Muhammad yang hadir pada peringatan maulid ini secara keseluruhan hendaknya jangan terbatas pada untuk meraih segala kebahagiaan di Dunia saja, tetapi juga hendaknya untuk meraih kebahagiaan di Akhirat.

Dapatkah cita-cita yang saudara anganangankan di benak saudara tersebut bila di Dunia telah tercapai nanti, untuk mengantisipasi/meraih sekaligus cita-cita kebahagiaan diAkhirat nanti? Wallohuallam. Untuk itu, kita sama-sama kembali ke agama Islam yang mengarah ke segala keseimbangan dan menuju ke kehidupan yang kekal dan abadi setelah melewati kehidupan yang singkat di alam Dunia yang fana ini.

Selanjutnya M: Ali Alkhuli mengatakan: "If we examine all the orders and laws of Islam, we find that every single law or order aims at ends with the happiness of the individual. This applies to Islamic regulations with regard to wor- ship, economics, penal laws, and all life aspects"

a. Bila seseorang percaya pada Allah, kepercayaan tersebut secara psikologis akan melahirkan suatu perasaan keamanan yang cukup kuat bagi orang yang bersangkutan. Orang tersebut akan lebih percaya diri dan mempunyai kewibawaan yang hebat pada saat-saat kritis serta tidak mudah putus asa maupun frustasi, karena orang yang demikian ini selalu di sampingnya untuk selalu menjaga dan menolongnya.

b. Seseorang yang percaya kepadaAllah, secara etik akan lebih bertanggungjawab dimana saja dia berada dan dalam waktu kapan saja, karena seseorang tersebut merasa selalu diawasi langsung tingkah lakunya oleh Sang Pencipta/Al-Khaliq.

c. Percaya terhadap hari kehidupan setelah mati (hari akhir), akan membuat seseorang muslim tidak sombong, takabur, rakus/tamak waktu masih hidup di dunia.

d. Seseorang muslim yang percaya adanya hari pembalasan/pengadilan di akhirat nanti, manusia akan selalu berusaha beribadah, beramal dan bertaqwa untuk memperoleh ridho Allah SWT. Orang tersebut akan selalu instropeksi pada diri sendiri, agar nantinya dapat memperoleh karcis ke surga penuh dengan bidadari, bidadari serta penuh dengan segala kebahagiaan yang kekal dan abadi.

e. Seorang muslim yang mengerjakan sholat lima waktu hari dan ditambah sholat sunnah akan lebih memperkuat hubungan antara manusia dengan Allah. Sebaliknya jika makin kurang dikerjakan Sholat tersebut, berarti akan absen/renggang pula hubungan 
Topik: In Memoriam Ace Partadiredja Kearah Pemikiran Ekonomi Kelembagaan

langsung antara manusia dengan Khaliqnya tersebut.

f. Manusia muslim yang mengerjakan puasa sebulan tiap tahun akan melatih manusia tersebut menjadi manusia yang dapat mengendalikan diri sendiri dari segala nafsu sehari-harinya. Lagi pula manusia tersebut akan dapat merasakan bagaimana saudaranya yang miskin, kelaparan tiap hari, sehingga akan membentuk pribadi yang lebih sabar dan dermawan.

g. Islam mengajarkan zakat, infaq dan shodaqoh untuk pemerataan distribusi pendapatan sehingga tidak akan terdapat lagi jurang pemisah yang dalam lagi antara si kaya dan si miskin.

Manusia diciptakan oleh Allah sekaligus diberi tugas sebagai khalifatullah (wakil Allah) di muka bumi berdasarkan keimanan yang kuat, menjalankan Rukun Islam dengan ikhlas serta beribadah sesuai dengan petunjukAilah dimana fungsi Islam yang harus diamalkan bersama paling tidak meliputi beberapa fungsi yaitu (Lihat lampiran I):

\section{a. Memerangi kebodohan}

Pengertian bodoh selama ini telah disamakan dengan seseorang yang tidak pandai baca, tulis serta berhitung. Islam mengajarkan bahwa orang yang bodoh yaitu orang yang tidak berakal. Orang yang tidak berakal adalah orang yang tidak memfungsikan akalnya secara baik, yaitu orang-orang yang menyembah, berbakti, takut, bekerja serta beribadah selain kepada Allah ta'ala.

Dengan demikian seseorang yang telah memperoleh gelar Profesor, Doktor di berbagai keilmuan namun jika dia menyembah dan takut pada berhala yang dibuat oleh manusia sendiri ataupun memuja kayu, batu ataupun hewan lain yang derajatnya lebih rendah dari manusia itulah sebodoh-bodohnya insan baik di dunia maupun di akhirat nanti. Jadi sseseorang yang tidak bisa baca tulis dan berhitung namun insan tersebut beribadah dan beramal mengikuti sunatullah insan ini dapat dikategorikan orang yang pandai dunia dan akhiratnya, terlebih-lebih kalau insan tersebut pandai juga baca tulis dan berhitung.

\section{b. Memerangi Kemiskinan}

Selama inj pengertian orang yang kaya adalah orang yang banyak mempunyai harta benda baik berupa uang, kendaraan, tanah dan rumah, saham dan lain sebagainya. Sedang sebaliknya jika tidak mempunyai berbagai hal tersebut insan tersebut dikategorikan sebagai orang yang miskin.

Islam mengajarkan orang kaya yang sebenarnya adalah bila sebagian besar dari rezeki yang diperoleh dan sekaligus merupakan titipan dari Allah tersebut telah diberikan pada 8 (delapan) asnah yang memerlukan yaitu: fakir, miskin, orang kehabisan bekal di perjalanan, orang terlilit hutang, mualaf, budak/hamba sahaya, fisabillah dan amil zakat bila memerlukan.

\section{c. Memerangi Kesakitan}

Banyak orang sakit yang di rawat di rumah sakit maupun di rumah dimana pada dasarnya Allah menurunkan penyakit dan Allah pula yang menyediakan obatnya, tinggal manusia sendiri dapatkah berikhtiar untuk sembuh bagi dirinya sendiri maupun keluarganya yang sakit. Namun orang yang sebenar-benarnya sakit dan sulit mengobatinya adalah orang-orang yang telah terutup/terkunci mata, telinga, hati dan kalbunya seperti yang tersurat dalam surat Al-Baqarah ayat 7. 


\section{d. Memerangi Kebatịlan}

Islam telah menunjukkan jalan yang lurus dan benar namun manusia banyak yang terperangkap dalam hal kebatilan guna memenuhi kehidupan kesehariannya karena telah teracuni pola hidup sekulerisme yang sangat mendambakan tuntutan nafsu guna memiliki harta benda sebanyak mungkin ataupun untuk mencari kedudukan setinggi mungkin dengan menghalalkan segala cara.

Hal ini harus dijauhi oleh semua manusia termasuk insan akademis pada umumnya serta para peserta seminar khususnya. Dalam hal ini manusia harus pandai-pandai mengelola otak/fikiran dan akhirnya otak manusia tersebut harus dapat - mengelola nafsu sebagai yang telah digariskan oleh kalbu/hati nurani manusia itu sendiri. (Lihat lampiran 2)

\section{Etika sebagai Indikator Kualitas Sumber Daya Manusia dan Keberhasilan Sistem Ekonomi}

\section{Etika Sebagai Indikator Kualitas Sumber Daya Manusia}

Etika dari kegiatan manusia baik sebagai individu maupun kelompok akan sangat menentukan kualitas dan produktivitas dari sumber daya manusia sendiri. Bagi manusia yang berilmu, beretika keimanan yang tinggi akan menjadikan diri manusia itu lebih terhormat di lingkungan masyarakat setempat bahkan di hadapan penciptaNya.

Terlebih dahulu perlu diberikan pengertian tentang ilmu pengetahuan baik secara umum maupun secara religius khususnya menurut pandangan Islam.

Definisi secara umum adalah sebagai berikut:
Science is a branch of knowledge or study dealing with a body of fact or truths systematically arranged and showing the operation of general laws" (The Random House Dictionary of the English Language College Edition)

Sedangkan pengertian ilmu menurut Imam Malik:

"IImu adalah nur (cahaya) yang dicurahkan Allah SWT. Kepada siapa yang Allah kehendaki, dan bukan disebabkan banyaknya riwayat yang dimiliki seseorang"

Allah dalam menciptakan manusia terdiri dari 6 (enam) unsur sumber daya insani yang meliputi:

a. Cahaya Tuhan (nur al--llahi/sirrullah).

b. Ruh (yang telah diberikan pada janin setelah usia kehamilan sekitar 3 bulan dalam rahim ibu)

c. Kalbu/hati nurani (yang merupakan tempat vital bagi kualitas manusia dimana bila hati nurani manusia tersebut baik maka baiklah manusia itu secara keseluruhan dan sebaliknya jika buruk maka buruk pula akhlak dan martabat manusia secara keseluruhan).

d. Akal (merupakan sumber pemberi inspirasi dalam hal berfikir untuk berkreasi, memproses segala sesuatu obyek yag dapat ditangkap oleh indra manusia baik untuk dinilai kebenarannya, direkam/disimpan atupun untuk dikeluarkan kembali dalam bentuk memori untuk diproses lebih lanjut). Akal merupakan alat prosesor yang handal dan tak akan dapat diganti oleh peralatan komputer model apapun yang dibuat oleh manusia.

e. Nafsu (hati sanubari merupakan sumber ataupun hasil dimana manusia mempunyai keinginan yang luar biasa/ serta tidak terbatas namun jika nafsu ini dapat dikendalikan oleh akal dan 
akal masih dapat dikendalikan oleh kalbu akan menghasilkan sesuatu/ amalan yang baik/positif. Tapi jika sebaliknya dimana nafsu menjadi dominan mengendalikan akal dan akal mengeliminir kebenaran kalbu maka akan melahirkan manusia yang berkualitas rendah bahkan lebih rendah dari derajat binatang)

f. Raga (cahaya Allah, roh, kalbu, akal dan nafsu secara keseluruhan dibalut dikemas olah raga/badan secara fisik maka berbentuklah manusia seperti kita ini). (Lihat lampiran 1).

Dengan demikian ilmu yang di cari adalah ilmu yang harus dapat mendekati kebenaran yang hakiki dan diterapkan oleh manusia yang menyatukan sumber dayanya yang sangat potensial untuk memakmurkan bumi demi kebahagiaan jasmani dan rohani/ material dan spiritual guna keperluan dunia dan akhiratnya. Salah satu cara untuk meningkatkan sumber daya manusia adalah melalui pendidikan.

Kemampuan berinovasi sangat tergantung pada proses belajar dan mengajar melalui pendidikan yang bermuatan ilmu pengetahuan dan teknologi yang dilandasi dengan kekuatan iman serta ketakwaan kepada Tuhan Yang Maha Esa dalam rangka membangun masyarakat yang madani yaitu masyarakat yang sopan santun, beradab dan berbudaya tinggi dimana dalam menghadapi berbagai permasalahan besar atupun kecil, yang rumit ataupun yang mudah selalu dicarikan jalan keluar dengan cara bermusyawarah dan mufakat antar sesama manusia dan dipertanggungjawabkan pada Tuhan sang pencipta.

Dalam hal ini Perguruan Tinggi di Indonesia pada umumnya dan Universitas Airlangga Surabaya khususinya dituntut berperan lebih aktif dalam melaksanakan visi dan misinya dalam rangka mewujudkan pembangunan sumber daya manusia yang berkualitas serta skaligus dapat menerapkan ilmu pengetahuan dan teknologi yang bermanfaat dalam membangun masyarakat madani yang mandiri.

Untuk memperoleh suatu kebenaran dimana derajat kebenaran itu sendiri terdiri atas:

1. Kebenaran yang mendasarkan pada suatu keilmuan (ilmal yakin)

2. Kebenaran yang mendasarkan pada suatu keilmuan dan dapat dilihat faktanya (ainul yakin)

3. Kebenaran yang sekaligus berdasarkan ilmu pengetahuan dan dapat dilihat secara nyata serta dapat dirasakan.

Contoh lebih jelasnya kita percaya bahwa di ruangan/halaman yang kelihatannya kosong itu sebenarnya ada udara (ilmu yakin), namun setelah dilihat pohon bergoyang karena ditiup angin/udara yang mengalir maka kebenaran tersebut sampai pada derajat ainul yakin. Selanjutnya setelah kita merasakan sejuknya hembusan angin tersebut, maka tingkat kebenarannya telah mencapai pada haqqul yakin.

limu itu sendiri merupakan salah satu dari sekian pengetahuan, dan kadangkadang disebut dengan nama pengetahuan itmiah (scientific knowledge) karena metode untuk memperolehnya dilakukan melalui metode ilmiah. Secara epostemologis kegiatan berfikir ilmiah ini meliputi suatu rantai berfikir secara logis yang merupakan pengkajian sesuatu yang umum (general) untuk menghasilkan sesuatu yang khusus (specific); ini yang kita kenal dengan logika berfikir edukatif. Dalam berfikir secara deduktif diperlukan satu sarana berfikir yaitu dengan menggunakan sarana matematika, 
sedangkan sebaliknya cara berfikir secara induktif kita pakai sarana statistika.

Dalam matematika sebagai alat berfikir itu sendiri sebenarnya adalah hanya merupakan suatu perjanjian yang statis dimana belum memasukkan dimensi ruang dan waktu sehingga masih patut kita ragukan derajat kebenarannya.

Contoh : angka 0 (nol) bila sendiri ataupun dituliskan di depan angka yang lain maka angka 0 (nol) tersebut tidak mempunyai nilai seperti halnya: 001 ataupun 007. Angka 0 (nol) baru mempunyai nilai bila dituliskan di belakang angka sperti halnya: 10,110 dan lain sebagainya.

- Demikian juga $1 \times 0$ (tidak diapaapakan) $=0$, seperti halnya $13 \times 0=0$, memang perjanjiannya demikian. Yang aneh dalam matematika 1:0 $=11: 0=\sim$. Sebaliknya $3+0=3-0$ (ini baru benar).

Dalam matematika tradisional diajarkan mangga 5 dimakan/dikurangi 2 tinggal mangga 3 . Bola 7 ditambah bila $3=$ bola 10. Mangga 3 ditambah bola 2 tidak dapat dijumlahkan.

Dalam matematika modern diajarkan peralatan berfikir sebagai berikut:

- Himpunan ayam $3 \div$ himpunan ayam $2=$ himpunan ayam 5

- Himpunan telor $5+$ himpunan telor $4=$ himpunan telor 9 .

Sedangkan himpunan ayam betina $1+$ himpunan telor bebek 9 tidak dapat dijumlahkan karena tidak homogen/ heterogen (sesuai dengan perjanjian statis baik pada matematika tradisional maupun matematika modern).

Hal ini berbeda dengan prinsip dasar matematika yang tertera pada surat An Nabaa' yaitu himpunan bumi/tanah (ayat 6 ) + himpunan sinar matahari (ayat 13) + himpunan air (ayat 14) + himpunan 1 benih (ayat 15) = menjadi himpunan kebon-kebon yang hebat (ayat 16).

Jelasnya himpunan tanah + himpunan sinar matahari + himpunan iar + himpunan 1 biji jagung setelah sekitar 105 hari akan menjadi 1 bengkol buah jagung yang mempunyai sekitar 500 biji. Jika dalam himpunan tersebut di atas yang ditambahkan adalah himpunan 1 bij/ 1 butir gabah maka setelah sekitar 3 bulan akan menjadi himpunan 200 gabah.

Demikian juga halnya himpunan 1 ayam betina + dengan himpunan telor ayam 9 setelah sekitar 21 menjadi himpunan ayam 10.

Jika sistem penghimpunan tersebut di atas telah memasukkan unsur ruang dan waktu dengan jenis himpunan yang heterogen/berbeda ternyata telah menghasilkan produk secara deret ukur ganda yang tidak beraturan. Inilah yang disebut dengan dinamic-holisticmatematics. Di sini berarti jika harus merevisi matematik dan statistik terlebih dahulu jika kita menginginkan kebenaran pada derajat yang haqqul yakin bukan sekedar ilmal yakin atas perjanjian yang statis.

Dalam matematika yang dinamis ada yang menggelikan dimana himpunan 1 ayam lapar + himpunan jagung 1 ons setelah 5 menit tinggal menjadi himpunan 1 ayam yang kenyang namun himpunan jagungnya sudah tidak tampak lagi (yang seharusnya himpunan tersebut bertambah malah hasilnya jadi berkurang).

Pada tahun 732 Masehi setelah seabad meninggalnya Rosullullah ilmu pengetahuan di dunia Islam berkembang sangat pesat baik ilmu sastra, matematika, fisika, kimia, kedokteran, astronomi maupun filsafat. Seorang saintis besar Ibnu Sina telah mengembangkan ilmu kedokteran yang 
masih dipakai sampai sekarang di berbagai Universitas di Eropa. Ibnu al Haitham telah melahirkan karya besar di bidang fisika. Dia telah membuat alat optik yang mempunyai presisi tinggi dan telah menemukan bahwa lintasan cahaya telah mengambil jalan yang paling singkat dan cepat ketika berpindah dari satu keadaan/tempat ke keadaan ataupun tempat yang lain. Prinsip ini baru berabad-abad kemudian dikenal dengan Fermat's principle of Least Time yang diambil dari nama Pierre de Fermat seorang ilmuwan dari Perancis. Dalam periode yang sama muncul pula 3 orang ahli matematika yaitu Al Khawarizmi, Thabnit Ibn Qurra dan al Khayyami (Omar Khayam) dimana karya penting al Khawarizmi dalam bukunya Hisab al jabrwal Muqabalah yang akhirnya lebih dikenal dengan al jabar dewasa ini. Khawarizmi selain telah beberapa membuktikan teori pitagoras juga telah memecahkan beberapa persamaan linier yang biasa dipakai oleh para pedagang saat itu. Thabit Ibn Qurra selain bidang matematika juga mengembangkan bidang ilmu politik, tata bahasa dan anatomi binatang. Thabit Ibnu Qurra telah mampu memprediksi dimana posisi terbitnya bulan sabit pada setiap tanggal 1. Sedangkan Umar Khayam selain terkenal dengan puisi Rubaiyatnya juga telah dapat memecahkan persamaan pangkat 3 dan pangkat 4 .

Para penulis Isiam lainnya meliputi: Abu Yusuf,. Al-Mas udi, al-Mawardi, lbn Hazm, al Sarakhsi, al-Tusi, al-Ghazali, al-Dimashqi, Ibn Rushd, Ibn Taymiyyah, Ibn al-Ukhumwah, Ibn al-Qayyim, al-Shatibi, Ibn-Khaldum, alMaqrizi, al-Dawwani dan Shah Waliullah. Khusus untuk Ibn Khaldun telah mengembangkan "the dynamic of interdisciplina.y model dan telah dikembangkan pula oleh Dr. M. Umer Chapra dengan satu fungsi $G=f(S, N, W, g$ dan $j)$ dimana $G=$ The political authority/pemerintah, $\mathrm{S}=$ Shari'ah
(Peraturan/Perundang-undangan yang berlaku), $\mathrm{N}=$ Wealth or stock of resources (harta), $\mathrm{g}=$ development/growth dan $\mathrm{j}=$ justiceladil. Model Ibn Khaldun selanjutnya lihat lampiran 3. Ibnu Khaldun telah banyak menganalisis teori ekonomi makro secara multidisiplin jauh sebelum Adam Smith dinobatkan sebagai bapak ilmu ekonomi oleh pemujanya.

IImu pengetahuan terus berkembang dimana di Jepang dalam masa Meiji restorasi tahun 1869-1900. Kaisar telah memerintahkan untuk membuka pintu/ mendatangkan ilmu pengetahuan dari dunia Barat dan menganjurkan masyarakat Jepang untuk mendalami ilmu dari berbagai. negara yang telah maju. Pada tahun 1886 Pangeran itu mengemukakan satu-satunya cara untuk meningkatkan kekuatan bangsa manjamin kelangsungan hidup rakyat adalah dengan memanfaatkan ilmu pengetahuan dan teknologi. Jepang dewasa ini telah maju pesat baik dalam hal penguasaan maupun penerapan ilmu pengetahuan juga telah berkembang dengan pesat namun perlu diingat ilmu pengetahuan dan teknologi bukan segala-galanya bagi umat manusia karena selain mendatangkan keuntungan juga banyak mendatangkan kerugian baik bagi manusia mupun lingkungan hidup serta makhluk yang lain.

Manusia tidak akan dapat menerangkan kapan lahir/timbulnya alam semesta ini dan kapan pula berakhirnya hanya Allah SWT. yang maha tahu. Seperti telah diuraikan terdahulu bidang matematika yang sematamata mengandalkan kekuatan rasio ternyata dalam kenyataan yang ada di dunia belum tentu benar. $\mathrm{Hal}$ ini telah dikemukakan oleh Godel ahli logika Hongaria dengan teori ketidaklengkapannya hingga pada akhir hayatnya Godel selalu memikirkan dunia irasional yang lain. Dalam ekonomi makro dikenal teori tartial dan gen- 
eral equilibrium dimana keseimbangan umum akan terjadi bila telah terdapat proses keseimbangan parsial di berbagai pasar baik dalam pasar dalam pasar barang dan pasar jasa, pasar uang dan pasar modal, pasar tenaga kerja maupun pasar makhluk lain.

Dengan demikian berbagai kejadian dalam kegiatan sosial ekonomi sangat sedikit yang dapat diramalkan secara matematis bahkan yang dapat terbukti masih kurang dari 1,0\%. Di bidang aseanografi yang tenang kedatangan suatu kapal yang berlayar dapat diprediksi dengan tepat secara linier, tetapi belum terdapat seorang manusiapun yang dapat memprediksi posisi/lokasi kapal bila telah masuk daerah turbulensi air sebagai sistem chaos.

Dalam sejarah pembangunan ekonomi Orde Baru yang telah menerapkan teori pembangunan struktural dari Colin Clark \& A.G.B. Fisher seta Fourastie (lihat lampiran 4) dan teori lepas landas dari W.W. Rostow (lihat lampiran 5) berdasarkan pengalaman pertumbuhan ekonomi dan perubahan struktur kegiatan ekonomi secara sektoral di Amerika dari tahun $1820 \mathrm{~s} / \mathrm{d}$ 1970. Pada tahun 1978 berdasarkan urban unemployment survey di berbagai kota di Indonesia (oleh Gavin Jones dan Suroso Imam Zadjuli) telah meramalkan bahwa dalam 20 tahun yang akan datang 1998 Indonesia akan mengalami pengangguran struktural yang hebat dan diawali dari daerah perkotaan seperti halnya Jakarta dan Surabaya. Demikian halnya tentang crass landing akan terjadi di Indonesia sebagai akibat dari pembangunan ekonomi yang mengandalkan pada hutang Luar Negeri yang dipraktikkan dengan sistem fiscal development dan berorientasi pada teori Rostow (diramalkan pada saat kongres ISEl di Bali). Ekonomi yunior yang meramalkan bahwa Indonesia akan dilanda pengangguran secara struktural dan sekaligus crass landing telah dimarahi habis-habisan oleh ekonom senior yang pada waktu itu menjabat sebagai Menteri Ekuin, Kepala Bappenas serta dimarahi pula oleh Menteri tenaga Kerja pada waktu itu. Bahkan pernah tidak ditegur oleh Menteri Keuangan dalam periode yang sama. Saksi hidup yang tahu masalah ini adalah beliau Prof. Dr. Sri Edi Swasono, Mayjen (Purn) Haridi Darmawan dan Salah seorang mahasiswa S-3 limu ekonomi yang hadir saat ini yaitu saudara Drs. Ec. H.M. M. Arie Mooduto. Peramalan tersebut berdasarkan keadaan yang telah terjadi. (Lihat lampiran 6,7, 8, 9, dan 11).

Dalam ilmu politikpun perlu reformasi. Misalnya pengertian tentang "democracy" yang berarti (Government by the people, a form of government in which the supreme power is vested in the people and ecercise by the or their elected agents under a free electoral system). Dalam sistem demokrasi ini jika memilih pemimpin/presiden berlaku suara "one man one vote". Jadi setiap orang mempunyai 1 suara baik dia seorang jeneral, guru besar, pengemis maupun pencopet suaranya sama. Tidak ada perbedaan tingkat intelektual maupun profesionalisme dalam orang perseorangan sehingga yang diaggap menang/yang benar adalah yang memperoleh suara terbanyak. Padahal Islam mengajarkan yang benar adalah yang mengikuti sunatullah walaupun yang mengatakan hanya satu orang saja. Jadi tidak heran kalau kita memperoleh presiden Bung karno, Pak harto, B.J. Habibie, Gus Dur dan Ibu Mega adalah merupakan hasil suara terbanyak, suka atau tidak itulah hasil rekayasa matematika demokrasi sekuler yang diagung-agungkan selama ini. Bahkan Ibu Mega telah menyebutnya bahwa beliau telah memimpin pemerintahan bagaikan pemerintahan keranjang sampah. Ini adalah suatu resiko 
Topik: In Memoriam Ace Partadiredja Kearah Pemikirar Ekonomi Kelembagaan

yang harus kita bayar dalam menganut sistem demokrasi dengan perhitungan matematika sekuler.

Dalam zaman kekhalifahan setelah Rosulullah meninggal diantara Abubakar, Umar, Usman dan Ali saling berebut mundur pada saat ditunjuk sebagai pengganti Rosulullah sedangkan sekarang saling kursi walaupun dengan cara politik dagang sapi yang fiktif disertai pengerahan masa secara profikatif lengkap dengan money politics.

\section{Etika Sebagai Indikator Keberhasilan Sistim Ekonomi}

Dalam ilmu ekonomipun banyak kesalahan yang telah terjadi dimana telah terdapat 10 sistim ekonomi besar di dunia yang gagal seperti halnya:

\section{a. Mekantilis}

Sistem ekonomi merkantilis yang menghasilkan ekonomi kolonialisme jelas tidak sesuai dengan harkat dan martabat/ hak asasi manusia, sehingga setelah banyak negara jajahan yang merdeka maka habislah riwayat ekonomi kolonial tersebut.

\section{b. Klasik dan Neo-Klasik}

Sistem ekonomi klasik yang lebih mengonsentrasikan diri pada pendekatan sisi penawaran (supply-side economics) dengan perdagangan internasional yang bebas dan kemudian dilengkapi oleh sistem ekonomi neo-klasik dengan pendekatan sisi permintaan (demand-side economics), juga telah hancur akibat terdapatnya perang tarif dan quota antar negara, sehingga keuntungan komparatif yang diimpikan akan diperoleh dari pedagangan internasional yang bebas tersebut, secara keseluruhan juga telah gagal.

\section{c. Kapitalis}

Sistem ekonomi kapitalis yang lebih mengandalkan pada investasi pemilikan faktor produksi lainnya oleh swasta serta distribusi dan perkembangan tingkat kemakmuran juga diserahkan sepenuhnya pada para individu serta perusahaan swasta dalam kondisi/persyaratan persaingan bebas juga tidak dapat dipertahankan lagi. Amerika yang merupakan pendekat utama negara kapitalis ini, telah menjadi korban dari sistem ekonominya sendiri.

Separo dari kekayaan dan keuntungan dari sebanyak 200.420 unit perusahaan industri di Amerika telah dimiliki/dikuasai oleh hanya 102 unit perusahaan industri raksasa saja (kekayaan rata-rata tiap perusahaan telah lebih dari satu milyard dollar US). Distribusi kemakmuran antar negara bagian juga tidak dapat merata, di mana negara federal sebelah Timur jauh lebih kaya bila dibandingkan dengan bagian sebelah Barat dan Kepulauan. Perbedan tingkat kemakmuran per kapita antara negara bagian yang berpendapatan rendah dengan yang berpendapatan tinggi ada sekitar US $\$ 10.000$,- per tahun.

Dewasa ini neraca pembayaran Amerika telah defisit dan terpaksa melepaskan perdagangan bebasnya dengan cara mengadakan Quota dan tarif terhadap pedagangan luar negerinya. Bahkan membekukan aset Republik islam Iran dan Libya yang berada di Amerika.

\section{d. Sosialis}

Sistem ekonomi sosialis baik di Eropa Barat (Sosialis Demokrat di Inggris) dan Eropa Timur di Polandia tidak mampu mempertahankan stabilitas ekonominya akibat sering timbulnya pemogokan serikat pekerja baik karena tuntutan kenaikan gaji maupun lebih menginginkan kebebasan 
terhadap tekanan dari pihak' majikan/ peguasa perusahaan serta pemerintahan.

Masalah peningkatan produktivitas, neraca pembayaran internasional serta inflasi merupakan masalah yang belum pernah terselesaikan hingga dewasa ini. Dalam periode 1973-1984 rata-rata inflasi di Inggris setahun mencapai $13,8 \%$ dan di Polandia sebesar $19,4 \%$. Dewasa ini pengangguran terbuka baik di Inggris maupun Polandia telah lebih dari 10,0\%.

\section{e. Komunis}

Sistem ekonomi komunis mulai dipakai sejak setelah revolusi Rusia tahun 1917. Namun ternyata sistem ini tidak dapat bertahan lama di negara kelahiran Karl Marx tersebut, sebab Alexander Kerensky menggantikan dengan sistem Sosialis Demokrat yang kemudian juga hancur dan diganti dengan sistem Sosialis Diktator oleh Lenin.

Karena sistem ini juga tidak berhasil, maka Lenin mengambil kebijaksanaan yang berbau kapitalistis yang sering disebut dengan "Step backward in order to take two steps a head (The New Economics Policy). Kebijaksanaan sistem kapitalis yang diambil tersebut antara lain: memperluas lembaga perbankan dan moneter lainnya, modal asing dapat masuk, tenaga ahli teknologi dari negara kapitalis diminta bantuannya untuk menangani industri berat serta sektor pertanian dapat diusahakan oleh perusahaan swasta.

Sejak di sini tamatlah sistem ekonomi komunis di Rusia. Komunis di China semula mengikuti jejak Uni Soviet/Rusia. Hingga Perang Korea selesai, China dengan perencanaan ekonomi terpusat ini hanya bertahan hingga tahun 1958 sejak "Great Leap Forward" diperkenalkan. Perencanaan secara desentralisasi di laksanakan dengan pemberian otonomi terhadap komuneindustri lokal dan kolektivisme pertanian di daerah.

Dewasa ini China telah melepaskan sistem ekonomi tertutup/lebih mengarah pada ekonomi terbuka yang kapitalistis. Komunis di Yugoslavia merupakan campuran antara Sosialis Demokrat dan Komunis Soviet, namun ternyata Yugoslavia yang semula tetap mempertahankan hubungan bebasnya dengan negara-negara Eopa dan Amerika serta dengan peranan peranan desentralisasi dan otonomi cukup luas, namun juga tidak dapat bertahan lagi dan dewasa ini Yugoslavia telah menjadi Bosnia yang tercabik-cabik oleh pemerintahan Serbia yang tragis. Di ketiga negara yang semula didominasi sistem komunis ini jelas sistem ekonomi komunistis murni sudah tidak dipakai lagi secara konsekuen.

\section{f. Sistem Ekonomi Berencana di Dunia Ketiga}

Sistem ini banyak dipakai oleh beberapa negara yang berkembang dalam periode 1960-1970 yaitu dianut oleh: India, Pakistan, Mesir, Mexico dan Indonesia (1960-1966). Dalam sistem ini kemacetan ekonomi akan didobrak lewat pengembangan industri berat (heavey industries tahe for frontal attack of the economic stagnation).

Hasil akhirnya sebagian besar proyek industri berat macet karena kurangnya dana domestik, terjadi inflasi yang kronis serta terdapat banyak pengangguran.

\section{g. Monetary Orde}

Kaum monetaris percaya bahwa semua permasalahan ekonomi akan dapat diselesaikan lewat kebijaksanaan moneter. ide hukum monetaris ini gagal pula, sebab telah terjadi penyimpangan fungsi lembaga perbankan dan keuangan serta uang sebagai 
alat tukar juga telah tidak dapat berfungsi penuh. Bank yang seharusnya sebagai lembaga pencipta kredit ternyata sebagian besar keuntungannya diperoleh dari perdagangan mata uang dan kertas berharga lainnya.

Uang sebagai alat tukar telah berubah menjadi mata dagangan. Terdapatnya penyelewengan fungsi ini mengakibatkan kekacauan dalam sistem moneter terutama yang menyangkut masalah peredaran uang dalam masyarakat dan timbulnya berbagai spekulasi di lembaga perbankan/ institusi keuangan lainnya pada saat terjadi masa krisis. Dengan demikian kaum monetaris ini juga tidak akan dapat menyelesaikan masalah ekonomi dari segi kebijaksanaan moneter saja. Selain itu lewat Kebijaksanaan Anggaran Negara yang devisit juga tidak dapat memperbesar kesempatan kerja ataupun menekan pengangguran.

\section{h. Orde Strukturalis}

Orde ini akan mencari jalan keluar dari kesulitan ekonomi negara lewat pembangunan ekonomi dengan perubahan kegiatan sektoral. Namun demikian hasil akhiryang diperoleh justru makin meluasnya sektor informal yang tidak sehat dan pengangguran secara struktural. Di Indonesia dewasa ini telah terdapat pengangguran lebih dari $15,0 \%$ dan penduduk miskin telah berjumlah sekitar 40 juta orang.

\section{i. Sistem Ekonomi Campuran}

Sistem ini merupakan campuran antara sebagian sub-sistem kapitalis, sub sistem sosialis dengan sub-sistem negara setempat. Dalam sistem campuran ini akan muncul berbagai kemungkinan, yaitu akan timbul kelompok kapitalis birokrat ataupun sosialis birokrat serta dapat juga muncul socio kapitalis birokrat. Hasil akhir dari asosiasi sub-sistem ekonomi ini adalah inefisiensi/high cost economy dan semakin merosotnya kesejahteraan masyarakat golongan menengah ke bawah.

\section{j. Post Industrial State Economy}

Setelah revolusi industri yang menghasilkan berbagai jenis teknologi baik yang berupa kemajuan di bidang teknik biologi, kimiawi maupun teknologi mekanik ternyata keberhasilan di bidang ekonomi harus dibayar dengan kerusakan sumber daya alam, manusia maupun lingkungan hidup yang lain. Peningkatan perkembangan ekonomi tidak dapat hanya diukur dengan indikator ekonomi saja, tetapi juga harus diikutkan indikator non-ekonomi sebagai alat pengukur keberhasilan pembangunan dalam suatu negara.

\section{Perspektif Etika Ekonomi Islam}

Ekonomi Islam baik di Dunia maupun di Indonesia yang merupakan negara berpenduduk muslim terbesar di Dunia mempunyai prospek perkembangan yang pesat mengingat Indonesia merupakan negara yang bermasyarakat religius/agamis dan ber-Pancasila.

Selama ini dalam masyarakat yang religius telah diterapkan sistem ekonomi campuran yang didominasi oleh sistem kapitalisme-materialisme yang sekuler sehingga sering menimbulkan gejolak baik di bidang sosial-politik dalam menegakkan negara kesatuan Republik Indonesia hingga sekarang. Hal ini diakibatkan karena telah terjadi brain washing pencucian otak mulai dari anak-anak sampai dengan orang dewasa tanpa memandang warna kulit, jenis suku, agama serta tingkat pendidikannya.

Hal ini dapat dilihat dalam berbagai hal yang mendasar sebagai berikut: 
1. Paradigma dasar dalam ekonomi yang kita ikuti selama ini adalah: sekuler, bebas nilai, materialistis dan SosialDarwinis. Sedangkan paradigma dasar dalam ekonomi Islam lebih memberikan tekanan pada nilai moral, kebersamaan dalam berperikemanusiaan serta keadilan dalam kesejahteraan sosial dan ekonomi.

2. Dalam hal alokasi sumber daya alam untuk memenuhi kebutuhan manusia telah terbentuk stigma pemikiran bahwa kebutuhan manusia serba tidak terbatas di stu pihak sedangkan di lain pihak terdapatnya keterbatasan sumber daya alam ataupun alat pemenuhan kebutuhan manusia sehingga menimbulkan persaingan yang saling mematikan antar pelaku ekonomi.

Islam mengajarklan bahwa sebenarnya kebutuhan manusia secara riil baik untuk kebutuhan hidup primer, sekunder maupun tersier adalah terbatas. Sedangkan alat pemenuhan kebutuhan manusia dengan memanfaatkan ilmu pengetahuan dan teknologi menjadi tidak terbatas sehingga akan menimbulkan kemitraan diantara para pelaku ekonomi.

Yang serta tidak terbatas pada diri manusia adalah keinginan nafsunya namun kemampuan daya beli riilnya tetap terbatas. Dalam sistem ekonomi Islam yang holistik maka tugas/fungsi sistem ekonomi Islam adalah untuk memerangi: kebodohan, kemiskinan, kesakitan dan kebathilan. (Lihat lampiran 1).

Dalam melaksanakan tugas kita sebagai manusia perlu kesabaran dan ketawakalan karena hidup ini pada dasarnya adalah hanya sekedar mampir minum di dunia yang penuh dengan ujian dan cobaan dari Allah dan jika kita melaluinya dengan ikhlas insya Allah kita akan selamat di dunia dan akhirat nanti.

\section{Sistem Ekonomi Islam Dalam Masyarakat Madani}

Sistem ekonomi adalah ilmu ekonomi yang dilaksanakan dalam praktek. Iimu ekonomi adalah suatu ilmu yang mempelajari tingkah laku manusia baik selaku individu maupun kelompok masyarakat (dapat berbentuk badan hukum maupun tidak serta dapat pula berbentuk penguasa/pemerintah), dalam memenuhi kebutuhan hidupnya baik kebutuhan material maupun spiritual (jasmani dan rohani), dimana kebutuhan tersebut cenderung mengarah menjadi tidak terbatas, sedangkan sumber pemenuhan kebutuhan tersebut sangat terbatas. Praktek perilaku ekonomi tersebut berupa bagaimana, untuk apa dan oleh siapa organisasi faktor-faktor produksi dilaksanakan, distribusi barang dan jasa serta peruntukannya dalam suatu negara diberlakukan.

Dengan demikian sistem Ekonomi Islam merupakan penerapan ilmu ekonomi dalam prktek sehari-hari bagi individu, keluarga, kelompok masyarakat maupun pemerintah/penguasa dalam rangka mengorganisasi faktor produksi, distribusi dan pemanfaatan barang dan jasa yang dihasilkan tunduk dalam peraturan/ perundang-undangan Islam (sunnatullah).

Sumber terpenting sistem Ekonomi Islam adalah Al-Qur'an, Al-Hadits dan suri teladan perilaku tindak ekonomi dalam zaman khalifah. Namun demikian hingga saat ini belum terdapat satu literatur pun yang mengemukakan tentang Sistem Ekonomi Islam secara totalisme/atau menyeluruh. Yang ada baru merupakan pembahasan secara parsial saja seperti 
halnya Zakat, Riba, Bank Islam dan lain sebagainya.

Sistem Ekonomi Islam adalah sistem ekonomi yang mandiri, jadi bukan merupakan sistem ekonomi liberal, komunis, sosialis maupun sistem ekonomi campuran.

Yang membedakan sistem Ekonomi Islam dengan sistem ekonomi yang lain adalah:

a. Asuransi Dasar/Norma Pokok ataupun aturan main dalam proses maupun interaksi kegiatan ekonomi yang diberlakukan. Dalam sistem Ekonomi Islam asumsi dasarnya adalah "Syaru'ah Islam" diberlakukan secara menyeluruh baik terhadap individu, keluarga, kelompok masyarakat, usahawan maupun pengusahal pemerintah dalam memenuhi kebutuhan hidupnya baik untuk keperluan jasmaniah maupun rohaniah.

b. Prinsip Ekonomi Islam adalah penerapan efisiensi dan manfaat dengan tetap menjaga kelestarian lingkungan alam.

c. Motif Ekonomi Islam adalah mencari "keberuntungan" di dunia dai diakherat selaku Khalifathullah dengan jalan beribadah dalam arti yang luas.

Pengertian Syariah adalah hukumhukum yang diberikan oleh Allah Tuhan Yang Maha Esa lewat para Rasul-Nya yang termuat dalam kitab masing-masing seperti halnya yang terdapat dalam kitab Taurat kepada nabi Musa A.S., Zabur yang diwahyukan kepada nabi Daud A.S., Injil kepada IsaA.S. sertaAI-Qur'an diwahyukan kepada nabi MUhammad S.A.W. Menurut Islam jumlah nabi-nabi memang terdapat ribuan banyaknya termasuk kemungkinan besar antara lain pembawa syariah/hukumhukum yang terdapat dalam kitab-kitab umat Hindu, Budha dan lain sebagainya. Dengan demikian Syariah Economics dapat berkonsentrasi pada:

\section{- Islamic Economics \\ - Christian Economics \\ - Hinduism Economics \\ - Buddism Economics. \\ Diharapkan religious/syariah econom-} ics dapat dimotori pengembangannya oleh pemikir ilmu ekonomi yang agamis dalam membentuk masyarakat yang madani.

Dalam membangun masyarakat madani perlu diuraikan terlebih dahulu tentang pengertian, kesiapan pilar pranata dan tata nilai dalam masyarakat.

Pengertian, pilar pranata dan tata nilai masyarakat madani dapat disarikan dari buku "Menuju Masyarakat Madani" yang disusun oleh H. Muhamad Hasyim, 1419 Hijiah sebagai berikut:

\section{a. Pengertian}

Pengertian Madani berunsur kata mim (广) dal (د) dan nun (ن) kemudian menjadi "tamadhana" yang berarti to become civilized yang berarti menjadi sopan dan beradab.

Jadi masyarakat yang madani adalah masyarakat yang sopan santun, beradab serta berbudaya tinggi. Perilaku masyarakat madani dalam menghadapi berbagai permasalahan baik persoalan yang besar maupun yang kecil, yang rumit maupun yang mudah selalu dihadapi dengan sopan santun dan berperadaban serta mencarijalan keluar dengan cara bermusyawarah baik dengan sesama manusia maupun bermusyawarah dengan Allah menurut Sunatullah-Nya.

Hati-hati dengan pengertian "Civil Society" yang selalu terkait dengan:

- Relating to the ordinary life of citizen

- Not military 
- Between citizen of the same country (civil war)

- Maintained for benefit of citizen (civil service)

- Polite, well-mannered

Untuk pengembangan masyarakat madani perlaku panutan/pemimpin dalam masyarakat. Pemimpin dalam masyarakat tersebut harus berfungsi yang meliputi:

- Dapat mempengaruhi tingkah laku masyarakat baik karena posisi maupun kewenangannya (by virtue of power and position).

- Dapat sebagai panuntun dan tempat bertanya karena posisi keilmuannya lebih dan karena kepribadiannya yang santun dan bertanggungjawab (by virtue of personality and ability)

\section{b. Pilar Pranata}

Pilar/tiang pranata yang harus dikembangkan untuk mewujudkan masyarakat madani adalah sebagai berikut:

1. Ulama atau ahli ilmu yang konsisten yaitu (cendekiawan, ilmuwan, ilmiawan atau pakkar/pakar) yang mempunyai kelebihan dari rata-rata masyarakat dalam bidang keahlian ataupun ilmu pengetahuan yang bersifat rasional atau perenial, dan memanfaatkan keahlian/keilmuannya selain untuk diri sendiri/keluarga/kelompoknya juga betul-betul untuk masyarakat banyak / luas (Ikhlasul Ulama):

2. Umara' yang mengemban kepemimpinan (kepemimpinan pemerintahan, swasta sosial politik). Umara' harus bersifat adil dan seimbang (equity and justice) terhadap masyarakat yang diemban/diabdinya (adalatul Umara)

3. Tujjar, pelaku perekonomian masyarakat (penggerak roda ekonomi masyarakat: pengusaha, pabrikasi, pedagang, pialang, perantara dan lain sebagainya) harus bersifat jujur dan tidak berkianat terhadap masyarakat serta lebih mensejahterakan masyarakat (Amanatut Tujjar)

4. Muhtarifun, pekerja/karyawan. Pekerja (karyawan harus setiap dalam melaksanakan tugas/profesi sebagai amanat yang dititipkan padanya (Nashihatul Muhtarifun).

5. Rakyat yang loyal. Terpenuhinya unsirunsur dalam masyarakat akan mewujudkan masyarakat madani yang loyal dalam bermasyarakat/ berbangsa dan bernegara (Al-Ibad)

\section{c. Tata Nilai Madanniah}

Untuk mewujudkan masyarakat madani di ata heterogenitas masyarakat baru dapat diubah menjadi masyarakat yang homogen dengan perekat nilai-nilai yang universal sebagai berikut:

1. Menciptakan nilai-nilai yang mampu memelihara eksistensi agama ataupun ajaran-ajaran yang ada dalam masyarakat (hifzuddin).

2. Menumbuhkan nilai-nilai yang mampu memelihara keamanan dan ketertiban serta keselamatan manusia yang dijamin hak dan kewajibannya (hifzun-nafs).

3. Menegakkan nilai-nilai yang menjamin/ menegakkan pemikiran manusia yang jernih (hifzul-aqh).

4. Menumbuhkan nilai-nilai yang menciptakan eksistensi kekeluargaan yang tenang dan tenteram dengan penuh silaturahmi (hifsun-nabal)

5. Membangun nilai-nilai yang mampu menjamin perkembangan ekonomi màsyarakat yang saling menguntungkan.

Islam: kebutuhan terbatas - sumber daya alam tidak terbatas 
Topik: In Memoriam Ace Partadiredja Kearah Pemikiran Ekonomi Kelembagaan

Kapitalis: kebutuhan tidak terbatas sumber aya alam terbatas, sehingga menimbulkan persaingan yang tidak sehat.

6. Nilai-nilai yang tidak memberatkan kewajiban masyarakat dalam berbangsa dan bernegara serta bermasyarakat (Al-Hajiyat).

Al-Hajiyat harus bersifat Raful masyaqqah ataupun Adamul haraj à deregulasi terhadap peraturan yang merugikan.

7. Nilai-nilai bebas memilih dari masyarakat terhadap alternatif yang paling menguntungkan dan santun, beradab serta bermoral tinggi (AlTaksiniyyat).

\section{Penutup}

Belajar dari berbagai kesalahan dalam penerapan ilmu sosial-ekonomi serta perangkat analisis matematika maupun statistik yang cenderung sekuler, bebas etika dan nilai terkonsentrasi pada material dan terdapatnya faham Sosial-Darwins yang telah menghasilkan berbagai kehancuran dan penjajahan baik di bidang sosialekonomi dan budaya, maka Islam telah memberikan tuntunan yang membawa manusia menjadi khalifatullah di muka bumi serta akan terjamin adanya moral dan etika bisnis dalam masyarakat yang madani, kebersamaan dalam berperikemanusiaan serta terdapatnya keadilan yang beradab dalam masyarakat yang makmur penuh dengan rahmat dan ridho dari Allah SWT.

\section{Daftar Pustaka}

Al-Qur’anul karim

Al-Hadist.

Amin Azis, 1992. "Mengembangkan Pengajaran IImu Ekonomi Islam di Indonesia" Berbagai Aspek Ekonomi
Islam, Yogyakarta, P3El Ull dan Tiara Wacana.

Abdul manan, Mohamed, 1987. Islamic Economic in Theory and Practice, London: Hodder and Stouhton, 425p (Revised and enlarge version of the author's Islamic Economics Lahore: Ashraf Publications.

Afzalur Rahman, Doktrin Ekonomi Islam, jilid I, II, III \& IV, Yogyakarta: Dana Bhakti Wakaf.

Al-Ghozali, Ilmu Dalam Perspektif Tasawuf Bandung: Penerbit Karisma

Conny R. Semiawan, Prof. Dr., I Made Putrawan, Dr., TH. I. Setiawan, Dr., Dimensi Kreatif Dalam Filsafat IImu, Bandung: Penerbit PT. Remaja Rosdakarya.

Islamic Development Bank, "Annual Report $1997-1998(1418 \mathrm{H})$

John Lindauer, 1971, Macroeconomics, Secnd Edition, Claremont, California.

Konsep Bank Syari'ah

Mohammad Umar Chapra, What /s /slamic Economics ?, IDB Prize Winners' Lecture Series No. 9, Islamic Development Bank, Islamic Research and Training Institute, Jeddah, Saudi Arabia.

Maulana Wahiduddin Khan, Religiuon and Science, Delhi: Printed by Nice Printing Press.

M. Umer Chapra, The Future of Economics an Islamic Perspective, The Islamic Foundation. 
Etika Sebagai Landasan Moral Pembangunan Ekonomi...; Suroso Imam Zadjuli

Syamsul Rijal Hamid, 1999. Buku Pintar Agama Islam, Edisi Senior, Jakarta: Penebar Salam.

Suroso Imam Zadjuli, 199.7. Makalah Potensi dan Prospek Lembaga Keuangan Syari'ah Dalam Era Globalisasi, Fakultas Ekonomi Universitas Airlangga.

1997, "Prinsip-Prinsip Ekonomi Islam" Berbagai Aspek Ekonomi Islam, Yogyakarta: P3EI UII dan Tiara Wacana.

1995, Makalah Peran Perbankan Syari'ah dalam Investasi Pembangunan, Surabaya: Fakultas Ekonomi Universitas Airlangga.

1999, Makalah Dampak Krisis Ekonomi Terhadap Kondisi Sosial Ekonomi Kelompok Kelas Menengah ke Bawah, Surabaya: Fakultas Ekonomi Universitas Airlangga.
1999, Makalah Membentuk Manusia Menjadi Khalifah di Bumi Yang Makdanniyah, Surabaya: Fakultas Ekonomi Universitas Airlangga.

, 1986. Pembangunan Berimbang dasar Struktur Ekonomi daerah Jawa Timur, Surabaya.

2002, Makalah Reformasi IImu Pengetahuan dan Perspektif Ekonomi Islam, Surabaya: Fakutas Ekonomi Universitas Airlangga.

Volker Nienhaus, Prof. dr., economic Cooperation and Integration among /slamic countries: International Framework and Economic Problems, Islamic Development Bank, Islamic Research and Training institute, Jeddah, saudi Arabia.

Wiliam H. Mienyk, Economic, New York: Random House. 